\title{
Connecting Accuracy of Interchanged Prosthetic Abutments to Different Dental Implants Using Scanning Electron Microscopy
}

\author{
Piero Rocha ZANARDI \\ Bruno COSTA \\ Roberto Chaib STEGUN \\ Newton SESMA \\ Matsuyoshi MORI \\ Dalva Cruz LAGANÁ
}

Department of Prosthodontics, Dental School, USP - University of São Paulo, São Paulo, SP, Brazil

\begin{abstract}
The present study evaluated the interchangeability of prosthetic components for external hexagon implants by measuring the precision of the implant/abutment (I/A) interface with scanning electron microscopy. Ten implants for each of three brands (SIN, Conexão, Neodent) were tested with their respective abutments (milled $\mathrm{CoCr}$ collar rotational and non-rotational) and another of an alternative manufacturer (Microplant) in randomly arranged I/A combinations. The degree of interchangeability between the various brands of components was defined using the original abutment interface gap with its respective implant as the benchmark dimension. Accordingly, when the result for a given component placed on an implant was equal to or smaller then that gap measured when the original component of the same brand as the implant was positioned, interchangeability was considered valid. Data were compared with the Kruskal-Wallis test at $5 \%$ significance level. Some degree of misfit was observed in all specimens. Generally, the non-rotational component was more accurate than its rotational counterpart. The latter samples ranged from 0.6-16.9 $\mu \mathrm{m}$, with a $4.6 \mu \mathrm{m}$ median; and the former from 0.3-12.9 $\mu \mathrm{m}$, with a $3.4 \mu \mathrm{m}$ median. Specimens with the abutment and fixture from Conexão had larger microgap than the original set for SIN and Neodent $(\mathrm{p}<0.05)$. Even though the latter systems had similar results with their respective components, their interchanged abutments did not reproduce the original accuracy. The results suggest that the alternative brand abutment would have compatibility with all systems while the other brands were not completely interchangeable.
\end{abstract}

Key Words: dental abutments, dental implants, dental prosthesis design, scanning electron microscopy, prosthesis fitting.

\section{INTRODUCTION}

Following the parameters established for the Branemark implant system, several alternative components closely resembling the original design were introduced to compensate for technical and cost limitations. Apparently, the equivalence provided by this manufacturing standardization and the inevitable machining tolerance would make the abutments from different brands interchangeable. This could be helpful for some clinical situations and offer a flexible working resource when selecting an abutment for similar implant designs. It could also be positive for a patient, for instance, who is to change dental office, by permitting easy identification and servicing of the prosthesis components (1).

However, the extent to which this practice could be adopted within the plurality of the market should be critically ascertained $(1,2)$, especially with respect to the magnitude of the resulting interface discontinuity between the prosthetic component and the implant. In a pioneering work, Binon et. al (3) studied switching platform combinations and proposed that the adequacy of the exchange should be defined by the precision of the fit verified when the original components were used.

The misfit between the implant and its abutment (I/A) has an important role in the maintenance of the bone/implant/prosthesis complex when managing biomechanical response and bacterial contamination. The I/A microgap allows the passage of fluids $(4,5)$ 
and is the gateway for bacteria that colonize the implant interstice (6-8), which seems to contribute to bone loss around the implant. In static experiments, the infiltration problem has reportedly been controlled $(4,9)$. However, in vitro studies with simulated chewing cycling demonstrated that the misfit allows for movement of the prosthetic component $(7,8,10)$. As the interface gap widens, so does the observed movement (11) which may lead to serious problems such as screw loosening $(2,12-14)$. On the other hand, reducing this gap appears to decrease the tensions generated in the system as a whole $(4,5,11,15,16)$.

Since it has become commonplace to employ an abutment regardless of the brand of the implant and even choosing components produced independently for the various prosthetic implant systems, the potential for significant precision problems may be even greater than expected when all the elements are furnished by the same manufacturer. However, studies that actually compared the precision of alternative and original components are lacking. The objective of this research was to evaluate existing discrepancies at the I/A interface of three commercial implant systems with their original abutments, when they were interchanged and when an alternative component was used.

\section{MATERIAL AND METHODS}

Three brands of external hex implants (SIN; SIN Implant Systems, São Paulo, SP; CON; Conexão Sistemas de Próteses, Arujá, SP; NEO; Neodent, Curitiba, PR) produced in Brazil (10 for each brand) were tested with their respective abutments (10 rotational and 10 non-rotational) and with an abutment from an alternative manufacturer (MIC; Microplant Sistemas de Próteses, São Paulo). All components had a pre-milled cobalt-chromium collar. Specimens were arranged so that all possible $\mathrm{I} / \mathrm{A}$ combinations were assembled using a latin square grid for complete randomization (1). The accuracy of the I/A interface was quantified by the vertical discrepancy $(1,2,17-21)$ between the surface of the implant and the abutment. Horizontal and angular discrepancies were not considered at this time, although they clearly may represent further complication of any observed vertical difference.

The components were initially submerged and thoroughly cleaned in an ultrasonic bath with an enzymatic detergent (Riozyme III; Indústria Farmacêutica Rioquímica Ltda. São José do Rio
Preto, SP, Brazil) and mounted with a torque wrench (Microplant Sistemas de Próteses, São José do Rio Preto, SP, Brazil), and a $20 \mathrm{~N} / \mathrm{cm}$ load. The I/A set was mounted on a plastic rectangular support (Fig. 1) which defined two assessment positions: front and back. Using aluminum tape, these blocks were placed into the scanning electron microscope (Leo 430i 15 $\mathrm{kV}$, JEOL, Japan) and the images were made at $\times 1,000$ magnification. Measurements were taken directly on the microscope at four randomly selected locations (two front and two back). For statistical analysis, the highest value for each specimen was considered as the representative gap measurement at the I/A interface. Data were compared with the Kruskal-Wallis test at 5\% significance level.

\section{RESULTS}

No specimen presented complete vertical precision. The basic experimental premise was that the smaller this gap, the better the adaptation of the component as a whole. The highest value for each specimen were used in the experimental evaluation, since this is the most critical point of the implant/ prosthesis unit. These measurements are summarized in Tables 1 and 2.

The degree of interchangeability between the various brands of assembled components on a given fixture was defined using the original abutment interface gap with its respective implant as the benchmark dimension. Accordingly, when the result for the largest discrepancy for a given component placed on an implant

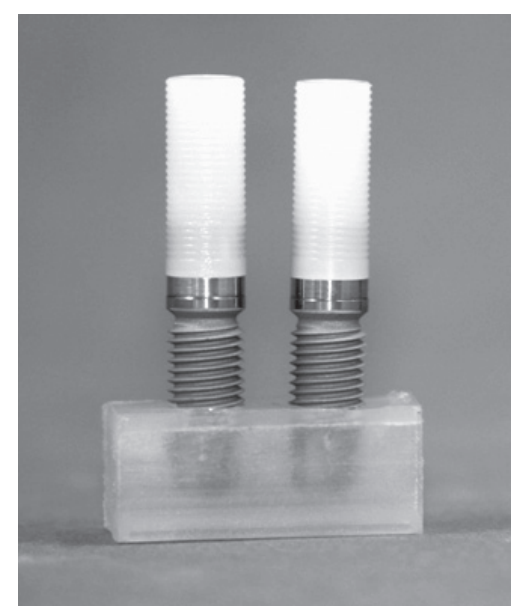

Figure 1. Plastic apparatus for positioning of the implant on the scanning electron microscope. 
is equal to or smaller than the same gap measured when the original component is positioned, interchangeability was considered valid.

When rotational abutments were considered, the MIC specimens presented gaps equivalent $(p>0.05)$ to those of the original component on the SIN implant, while both NEO and CON abutments showed significantly larger misfit $(p<0.05)$. On the NEO fixture, there was no difference when SIN and MIC abutments ( $p>0.05$ ) were placed but a significantly large misfit was observed for CON specimens $(p<0.05)$. Finally, on the CON implant, the SIN, NEO and MIC abutments demonstrated better results and lower misfit $(\mathrm{p}<0.05)$, when compared with the original abutment.

For the non-rotational group, the original abutments for the SIN implant were interchangable with

Table 1. Results for microgap $(\mu \mathrm{m})$ for rotational abutments.

\begin{tabular}{|c|c|c|c|c|c|c|c|c|c|c|c|}
\hline \multicolumn{4}{|c|}{ SIN } & \multicolumn{4}{|c|}{ NEO } & \multicolumn{4}{|c|}{$\mathrm{CON}$} \\
\hline SIN & NEO & $\mathrm{CON}$ & MIC & SIN & NEO & $\mathrm{CON}$ & MIC & SIN & NEO & $\mathrm{CON}$ & MIC \\
\hline 3.5 & 1.3 & 4.0 & 3.1 & 1.9 & 5.3 & 4.6 & 8.6 & 7.4 & 1.4 & 8.3 & 5.7 \\
\hline 3.7 & 6.6 & 6.1 & 2.6 & 5.4 & 0.6 & 10.1 & 4.1 & 5.6 & 7.6 & 11.2 & 5.6 \\
\hline 2.7 & 5.8 & 10.6 & 3.2 & 1.8 & 3.2 & 10.2 & 6.6 & 5.5 & 5.9 & 13.2 & 9.4 \\
\hline 2.6 & 4.5 & 7.3 & 5.7 & 3.5 & 1.6 & 5.8 & 2.8 & 9.5 & 10.9 & 8.7 & 9.1 \\
\hline 2.8 & 5.1 & 10.0 & 1.7 & 3.9 & 2.8 & 6.0 & 2.4 & 2.0 & 6.5 & 10.1 & 9.2 \\
\hline 2.0 & 1.6 & 13.6 & 3.3 & 4.0 & 1.1 & 10.6 & 2.7 & 0.6 & 6.2 & 11.2 & 1.2 \\
\hline 1.0 & 6.8 & 7.6 & 0.6 & 2.6 & 5.6 & 14.1 & 2.9 & 7.1 & 7.3 & 14.3 & 7.5 \\
\hline 2.1 & 4.6 & 8.0 & 2.4 & 1.0 & 3.4 & 7.8 & 4.4 & 5.4 & 1.7 & 11.5 & 4.0 \\
\hline 1.5 & 5.9 & 6.8 & 3.1 & 2.0 & 1.1 & 4.0 & 2.6 & 3.1 & 5.6 & 10.6 & 6.3 \\
\hline 4.1 & 4.4 & 16.9 & 2.1 & 3.3 & 4.0 & 5.5 & 3.6 & 3.2 & 10.2 & 6.4 & 4.2 \\
\hline
\end{tabular}

Bold lettered line refers to the component brand with each type of implant. SIN: SIN Implant Systems, São Paulo; CON: Conexão Sistemas de Próteses, Arujá; NEO: Neodent, Curitiba.

Table 2. Results for microgap $(\mu \mathrm{m})$ for non-rotational abutments.

\begin{tabular}{|c|c|c|c|c|c|c|c|c|c|c|c|}
\hline \multicolumn{4}{|c|}{ SIN } & \multicolumn{4}{|c|}{ NEO } & \multicolumn{4}{|c|}{ CON } \\
\hline SIN & NEO & $\mathrm{CON}$ & MIC & SIN & NEO & $\mathrm{CON}$ & MIC & SIN & NEO & $\mathrm{CON}$ & MIC \\
\hline 3.4 & 3.2 & 4.2 & 3.1 & 3.0 & 3.0 & 2.4 & 2.2 & 2.8 & 5.5 & 7.2 & 4.8 \\
\hline 4.6 & 2.5 & 6.2 & 4.0 & 2.4 & 1.8 & 4.0 & 4.6 & 1.0 & 6.0 & 8.6 & 5.7 \\
\hline 1.5 & 2.4 & 5.8 & 2.4 & 4.0 & 1.6 & 5.4 & 1.6 & 8.0 & 6.4 & 11.1 & 1.2 \\
\hline 2.8 & 2.6 & 6.2 & 3.6 & 3.0 & 2.2 & 4.0 & 1.2 & 0.3 & 11.3 & 4.5 & 1.5 \\
\hline 4.0 & 2.0 & 5.8 & 2.6 & 3.2 & 2.1 & 2.0 & 2.2 & 7.2 & 8.0 & 10.3 & 4.2 \\
\hline 2.0 & 2.5 & 3.4 & 3.0 & 3.4 & 1.4 & 4.6 & 3.4 & 5.6 & 4.2 & 7.8 & 4.2 \\
\hline 1.4 & 2.4 & 6.2 & 2.2 & 4.0 & 1.2 & 4.0 & 2.8 & 2.4 & 4.8 & 12.9 & 1.8 \\
\hline 3.8 & 1.2 & 6.2 & 2.0 & 4.6 & 1.8 & 5.4 & 1.4 & 3.2 & 6.0 & 7.7 & 4.0 \\
\hline 2.6 & 2.8 & 4.8 & 2.2 & 1.6 & 2.0 & 3.2 & 2.6 & 3.0 & 3.0 & 10.5 & 3.7 \\
\hline 3.6 & 4.6 & 4.6 & 2.2 & 3.0 & 1.6 & 4.0 & 3.2 & 6.5 & 9.6 & 7.0 & 7.2 \\
\hline
\end{tabular}

Bold lettered line refers to the component brand with each type of implant. SIN: SIN Implant Systems, São Paulo; CON: Conexão Sistemas de Próteses, Arujá; NEO: Neodent, Curitiba. 
NEO and MIC specimens ( $p>0.05)$, but not with CON components $(p<0.05)$, which presented a larger misfit. On the NEO fixture, SIN and CON abutments showed significantly larger misfits $(p<0.05)$, while the MIC specimens were equivalent ( $>>0.05)$. Finally, for the CON implant, all abutments were interchangable with NEO showing to be equivalent to the reference microgap $(p>0.05)$ and SIN and MIC abutments $(p<0.05)$ actually resulting in a lower misfit then the one measured for the original component.

Sample distribution indicated a non-parametric approach for the statistical analysis. The Kruskal-Wallis test results are shown in Table 3 and the modified notch box graph (Fig. 2 and 3) illustrates the median, range and confidence limit (22) for each test group. The results were further subdivided by the type of component: rotational and non-rotational. Generically, the latter sample ranged

Table 3. Results of interchange of implants and components (Kruskal Wallis test, $\mathrm{p}<0.05$ ).

\begin{tabular}{|c|c|c|c|c|c|c|c|c|}
\hline \multirow{3}{*}{ Implant } & \multicolumn{8}{|c|}{ Abutment } \\
\hline & \multicolumn{4}{|c|}{ Rotational } & \multicolumn{4}{|c|}{ Non-rotational } \\
\hline & SIN & NEO & $\mathrm{CON}$ & MIC & SIN & NEO & $\mathrm{CON}$ & MIC \\
\hline SIN & - & ns & $\mathrm{s}$ & ns & - & ns & $\mathrm{s}$ & ns \\
\hline $\mathrm{CON}$ & s & $\mathrm{s}$ & - & s & $\mathrm{s}$ & ns & - & s \\
\hline NEO & $\mathrm{s}$ & - & $\mathrm{s}$ & ns & $\mathrm{ns}$ & - & $\mathrm{s}$ & ns \\
\hline
\end{tabular}

s: significant; ns: non-significant. For each implant, the accuracy of the interface gap was considered in relation to the fit of the original abutment, subdivided in rotational and non-rotational type component. SIN: SIN Implant Systems, São Paulo; CON: Conexão Sistemas de Próteses, Arujá; NEO: Neodent, Curitiba. MIC: Microplant. from $12.9-0.3 \mu \mathrm{m}$, with a $3.4 \mu \mathrm{m}$ median; the former from 16.9-0.6 $\mu \mathrm{m}$, with a $4.6 \mu \mathrm{m}$ median

\section{DISCUSSION}

Since manufacturers adopted the Branemark dimensional standardization, switching between abutments manufactured by different companies but within this configuration seemed technically viable and clinically adequate. However, the data from SEM images demonstrate that not only interchanged but even the original components do not offer consistently a minimal I/A gap (Fig. 4 and 5). The statistical analysis revealed significant differences between the abutment and its implant when the brand and the type of component were varied.

Even in the absence of any discrepancy, finite element models have pointed to a potential lateral displacement of the implant/abutment set (11). Clearly when such a discrepancy is either inherent to the original set or when components are interchanged, the abutment stability may be compromised (23).

The discrepancies determined at the four measured positions showed a tendency of a closer fitting interface at one point and progressively misfitting to a maximum on the opposite side, suggesting a sloped aperture. It

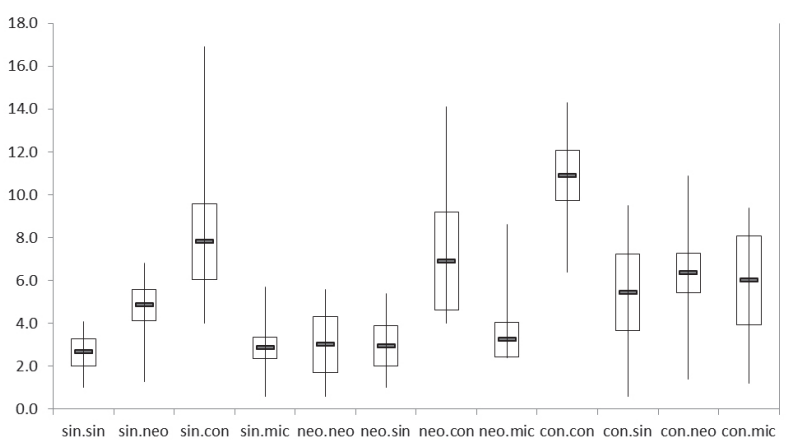

Figure 2. Modified notch box graph with the median (dash), general range (vertical line) and confidence limit (box), for the largest discrepancy values $(\mu \mathrm{m})$ distributed by implant brand and the prosthetic rotational component placed. SIN: SIN Implant Systems, São Paulo; CON: Conexão Sistemas de Próteses, Arujá; NEO: Neodent, Curitiba.

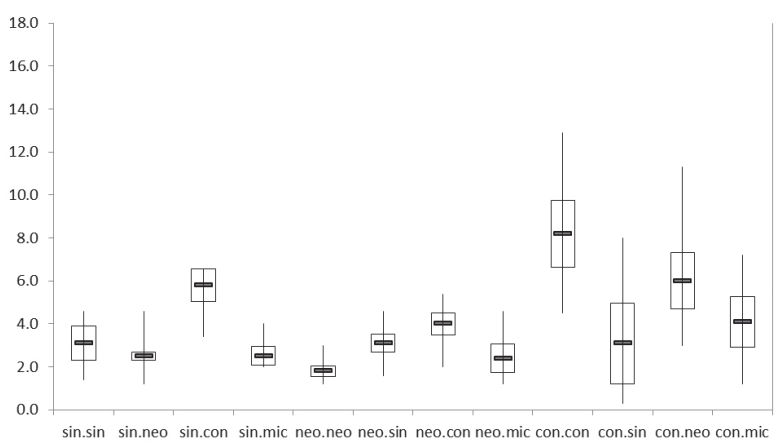

Figure 3. Modified notch box graph with the median (dash), general range (vertical line) and confidence limit (box), for the largest discrepancy values $(\mu \mathrm{m})$ distributed by implant brand and the prosthetic non-rotational component placed. SIN: SIN Implant Systems, São Paulo; CON: Conexão Sistemas de Próteses, Arujá; NEO: Neodent, Curitiba. 
is important to note that the used criterion assumed that the accuracy to be expected from any component exchange should at least duplicate that of the original abutment (3). According to this, rotational NEO and $\mathrm{CON}$ abutments were not exchangeable for the original SIN combination. However, SIN components were compatible with NEO and CON implants. The CON system had the highest original interface gap and its abutments had the worst performance when placed both on NEO and SIN implants. Conversely, when NEO and SIN abutments were used on CON implants the results were significantly better. The alternative brand, MIC, was compatible with all three systems.

On the other hand, non-rotational components SIN and CON were not exchangeable for the original NEO combination. However, NEO components were compatible with SIN and CON implants. As was the case in the rotational specimens, the CON system had the largest original interface gap and its abutment had the worst performance when placed both on NEO and SIN fixtures. When NEO and SIN abutments were used on CON implants the results were significantly better than for the original component. Again, the MIC components had similar or better fit than the original components.

Generally, the gaps observed in this experiment showed a significant difference in accuracy when abutments were interchanged. However, discrepancies within same brand components were also evident. The I/A data for CON were clearly larger when the medians and variability for the original sets were compared.

The mean differences observed here were

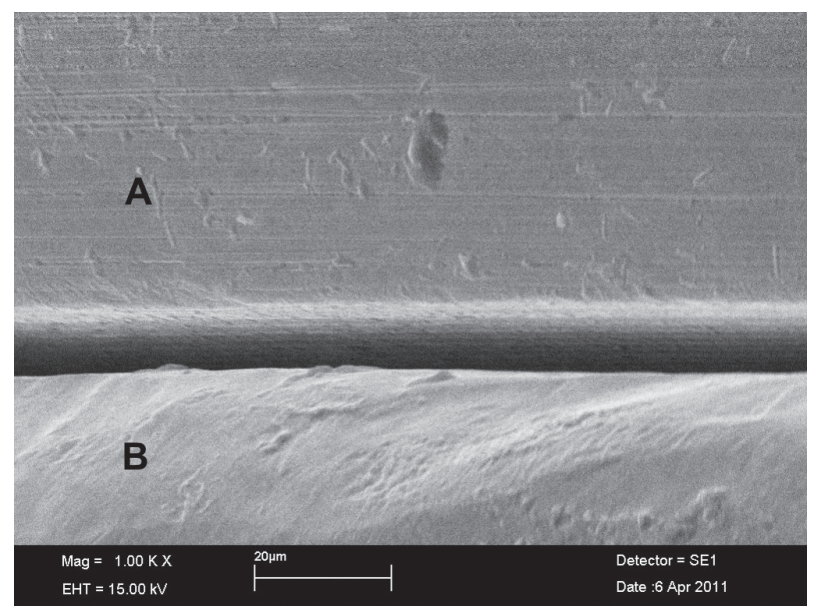

Figure 4. Largest microgap between the abutment (A) and the implant (B). Original magnification $\times 1,000$. similar to those found by Dellow et. al. (1) and larger than those found by Cheshire and Hobkirk (17) and Vidigal (18). However, the current results indicate a degree of machining error that may be, for the most part, quite favorable. For instance, given that a bacteria has an average size of $2 \mu \mathrm{m}$ (23), the required space for penetration into the inner part of the implant is very close to many of the maximum apertures for the evaluated components (6), since almost $41 \%$ of all of the data was equal to or below this figure and $70 \%$ smaller than $4 \mu \mathrm{m}$. Indeed, such a small microgap size may not be conducive to bacterial infiltration.

Only the alternative brand abutments proved to be consistently compatible with all systems tested. However, even components from Conexão that had the largest discrepancies, presented values that were much lower than those associated with biomechanical problems in the literature. Latest experiments have found magnitudes ranging from $50 \mu \mathrm{m}$ to $200 \mu \mathrm{m}(11,13,24)$, while in the present study, when considered the results as a whole, in $96 \%$ of the specimens the values were below the $10 \mu \mathrm{m}$ suggested by Branemark as ideal (25). Nevertheless, the clinical significance of the observed values must still be ascertained.

Within the limitations of this study, it may be concluded that the interchanged abutments from the different tested brands did not reproduce consistently the accuracy at the interface of the original component and its respective implant. The results suggest that, for the evaluated parameters, the alternative brand abutment would have compatibility with all three systems.

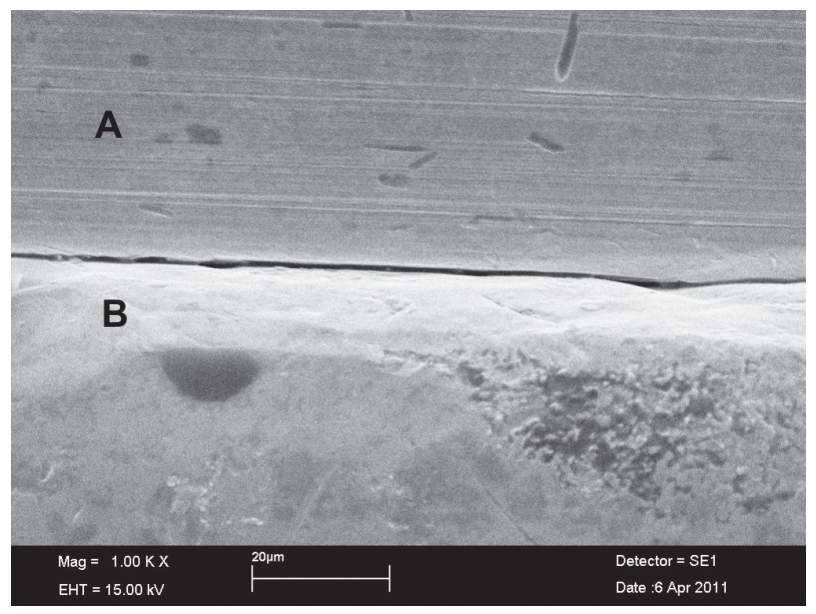

Figure 5. Smallest microgap between the abutment (A) and the implant (B). Original magnification $\times 1,000$. 


\section{RESUMO}

O presente estudo avaliou a intercambiabilidade dos componentes protéticos de implantes de hexágono externo medindo-se a precisão da interface implante/pilar com microscopia eletrônica de varredura. Foram utilizados dez implantes para cada uma de três marcas (SIN, Conexão, Neodent) com seus respectivos pilares (base metálica de $\mathrm{CoCr}$, rotacional e não rotacional) e um de marca alternativa (Microplant) em um arranjo com todas as combinações de implante/pilar possíveis. O valor de referência para a intercambiabilidade das várias marcas de componentes foi definido pela diferença do pilar original para com seu respectivo implante. Dessa maneira, a intercambiabilidade foi considerada válida quando o resultado para um dado pilar colocado sobre um implante fosse igual ou menor que a diferença medida quando o pilar da mesma marca do implante fora posicionado. Os dados foram comparados pelo teste de Kruskal-Wallis com nível de significância de 5\%. Um grau de desajuste foi observado em todos os espécimes. De uma maneira geral, o pilar anti-rotacional foi mais preciso do que o rotacional. Estes variaram de 0,6-16,9 $\mu \mathrm{m}$, com mediana $4,6 \mu \mathrm{m}$; enquanto o anti-rotacional foi de 0,3 $12,9 \mu \mathrm{m}$, com mediana de 3,4 $\mu \mathrm{m}$. Os espécimes com o pilar e o implante Conexão tiveram uma diferença maior que o conjunto original para SIN e Neodent $(\mathrm{p}<0,05)$. Apesar destes últimos apresentarem resultados semelhantes com seus respectivos pilares, quando trocados não mantiveram a mesma precisão original. Os resultados sugerem que a marca alternativa seria a única que apresentaria compatibilidade com todos os sistemas, enquanto as outras marcas não seriam completamente intercambiáveis.

\section{ACKNOWLEDGEMENTS}

The authors would like to acknowledge Prof. Dr. Victor Elias Arana-Chavez for his support in the methodology employed in this study.

\section{REFERENCES}

1. Dellow AG, Driessen CH, Nel HJC. Scanning Electron Microscopy evaluation of the interfacial fit of interchanged components of four dental implant systems. Int J Prosthodont 1997;10:216-221.

2. Binon P. Evaluation of Machining Accuracy and Consistency of Selected Implants, Standard Abutments and Laboratory Analogs. Int. J. Prosthodont 1995;2:162-179.

3. Binon P, Weir D, Watanabe L, Walker L. Implant component Compatibility. In: Laney W, Toiman DE (Editors). Tissue integration in Oral, Orthopedic and Maxillofacial Reconstruction, Chicago: Quintessence 1991:218-226.

4. Piattelli A, Scarano A, Paolantonio M, Assenza B, Leghissa GC, Di Bonaventura G, et al.. Fluids and microbial penetration in the internal part of cement-retained versus screw-retained implantabutment connections. J Periodontol 2001;72:1146-1150.

5. Gross M, Abramovich I, Weiss EI. Microleakage at the abutmentimplant interface of osseointegrated implants: a comparative study. Int J Oral Maxillofac Implants 1999;14:94-100.

6. do Nascimento C, Barbosa RE, Issa JP, Watanabe E, Ito IY, Albuquerque RF Jr. Bacterial leakage along the implant- abutment interface of premachined or cast components. Int J Oral Maxillofac Surg 2008;37:177-180.

7. Steinebrunner L, Wolfart S, Bossmann K, Kern M. In vitro evaluation of bacterial leakage along the implant-abutment interface of different implant systems. Int J Oral Maxillofac Implants 2005;20:875-881.

8. Rimondini L, Marin C, Brunella F, Fini M. Internal contamination of a 2-component implant system after occlusal loading and provisionally luted reconstruction with or without a washer device. J Periodontol 2001;72:1652-1657.

9. Duarte AR, Rossetti PH, Rossetti LM, Torres SA, Bonachela WC. In vitro sealing ability of two materials at five different implantabutment surfaces. J Periodontol 2006;77:1828-1832.

10. Rangert B, Jemt T, Jorneus J. Forces and moments on Branemark implants. Int J Oral Maxillofac Implants 1989;4:241-247.

11. Gomes EA, Assunção W, Tabata LF, Barão VA, Delben JA, de Sousa EA. Effect of passive fit absence in the prosthesis/implant/ retaining screw system: a two-dimensional finite element analysis. J Craniofac Surg 2009;20:2000-2005.

12. Binon PP. The effect of implant/abutment hexagonal misfit on screw joint stability. Int J Prosthodont 1996;9:149-160.

13. Assunção WG, Barão VA, Delben JA, Gomes EA, Garcia IR Jr. Effect of unilateral misfit on preload of retention screws of implant-supported prostheses submitted to mechanical cycling. J Prosthodont Res 2011;55:12-18.

14. Millington ND, Leung T. Inaccurate fit of implant superstructures. Part 1: Stresses generated on the superstructure relative to the size of fit discrepancy. Int J Prosthodont 1995;8:511-516.

15. Uludamar A, Leung $T$. Inaccurate fit of implant superstructures. Part II: Efficacy of the Preci-disc system for the correction of errors. Int J Prosthodont 1996;9:16-20.

16. Binon PP, McHugh MJ. The effect of eliminating implant/ abutment rotational misfit on screw joint stability. Int $\mathrm{J}$ Prosthodont 1996;9:511-519.

17. Cheshire PD, Hobkirk JA. An in vivo quantitative analysis of the fit of Nobel Biocare implant superstructures. J Oral Rehabil 1996;23:782-789.

18. Vidigal GM, Novaes AB, Chevitarese O, de Avillez RR, Groisman $M$. Evaluation of the implant-connection interface using scanning electron microscopy. Braz Dent J 1995;6:17-23.

19. Barbosa GA, Simamoto Júnior PC, Fernandes Neto AJ, de Mattos MaG, Neves FD. Prosthetic laboratory influence on the vertical misfit at the implant/UCLA abutment interface. Braz Dent $\mathrm{J}$ 2007; 18:139-143.

20. Barbosa GA, das Neves FD, de Mattos MaG, Rodrigues RC, Ribeiro RF. Implant/abutment vertical misfit of one-piece cast frameworks made with different materials. Braz Dent J 2010;21:515-519.

21. Oyagüe RC, Sánchez-Turrión A, López-Lozano JF, Suárez-García MJ. Vertical discrepancy and microleakage of laser-sintered and vacuum-cast implant-supported structures luted with different cement types. J Dent 2012;2:123-130.

22. McGill R, Tukey JW, Larsen WA. Variations of box plots. Am Statistician 1978;32:12-16.

23. Callan DP, Cobb CM, Williams KB. DNA probe identification of bacteria colonizing internal surfaces of the implant-abutment interface: a preliminary study. J Periodontol 2005;76:115-120.

24. al-Turki LE, Chai J, Lautenschlager EP, Hutten MC. Changes in prosthetic screw stability because of misfit of implant-supported prostheses. Int J Prosthodont 2002;15:38-42.

25. Brånemark PI, Zarb GA, Albrektsson T. Tissue-Integrated Prostheses: Osseointegration in Clinical Dentistry. Special edition for Nobelpharma Quintessence 1987:268-271.

Received April 3, 2012

Accepted October 31, 2012 